\title{
SEAGRASS BEDS DISTRIBUTION AND THEIR STRUCTURE IN THE SURROUNDING COASTAL WATERS OF KAPOPOSANG ISLAND, SOUTH SULAWESI
}

\author{
Nadiarti $^{1}$, Etty Riani ${ }^{2}$, Ita Djuwita $^{3}$, Sugeng Budiharsono ${ }^{4}$, Ari Purbayanto ${ }^{5}$ \\ ${ }^{1}$ Faculty of Marine Science and Fisheries, Hasanuddin University, Makassar, Indonesia, e-mail: \\ artinurdin@yahoo.co.uk \\ ${ }^{2}$ Study Program of Management of Natural Resources and Environment, Bogor Agricultural University, \\ Bogor, 16680 \\ ${ }^{3}$ Department of Anatomy, Physiology and Pharmacology, Faculty of Veterinary Medicine, Bogor \\ Agricultural University, Bogor, 16680 \\ ${ }^{4}$ Study Program of Management of Nature Resources and Environment, Bogor Agricultural University, \\ Bogor, 16680 \\ ${ }^{5}$ Department of Fisheries Resource Utilization, Faculty of Fisheries and Marine Sciences, Bogor \\ Agricultural University, Bogor, 16680
}

\begin{abstract}
Kapoposang Island and the surrounding waters has been appointed by Indonesian Governmet to be a part of waters tour park in South Sulawesi, implying the requirement of the marine resources, including seagrass ecosystems in this area, should be well managed in order to provide biodiversity protection and sustainable use of the seagrass ecosystems. For this purpose, one of basic required information is seagrass distribution and habitat structure. This study was aimed to 1) observe the location of continues seagrass beds, 2) identify the habitat structure in each site of continues seagrass beds. A combination of visual observation and transect method was applied to determine the sites of continues seagrass beds, while seagrass habitat structure was identified based on ecological habitat structure model. Study results revealed that continues seagrass beds were only found in five different sites of Kapoposang coastal waters. Seagrass habitat structure among the five sites were in variable and the highest seagrass cover was found in two sites, namely 1) site A in the north-west part of the island (S04 41'42.5"; E118 $\left.56^{\prime} 59.5^{\prime \prime}\right)$ dominated by Thalassia hemprichii and 2) site E located in the north part of the island (S04 41'57.8"; E1 18 57'45.7") dominated by Enhalus acoroides. Both of these sites were different in heterogeneity but similar in complexity.
\end{abstract}

Keywords: Thalassia hemprichii, Enhalus acoroides, continues seagrass beds, habitat structure

\section{Introduction}

Seagrasses are aquatic angiosperms, which have adapted to the marine, especially to the nearshore environment (Short et al. 2001). Although morphology of the seagrasses are closely similar to that of terrestrial grasses, botanically, seagrasses are more closely related to lilies than grasses as they have flowers and seeds (Koch et al. 2006). Furthermore, Kuo \& den Hartog (2006) described that morphologically, seagrasses consist of (1) adventitious roots that arise from the lower surface of the rhizomes, (2) rhizome and stems which provide function for anchoring, mechanical support, nutrient storage, and regulation and maintenance of vegetative growth, and (3) foliage leaf, that usually forms a unit of several leaves, and normally is referred to as a shoot.

Seagrass meadows is an important part of marine habitat in continental shelf waters and they have been found in almost all part of the world, except for Antarctic region (Hemminga \& Duarte 2000). Seagrass meadows are often the dominant primary producers in coastal areas, playing a key role in trophodynamics, habitat provision, substrate stability and biogeochemical cycling (Rasheed et al. 2006). The highest primary productivity of the seagrasses is found in the Indo-Pacific region (Hemminga \& Duarte 2000), where Indonesian waters are included, making the seagrass ecosystems play an important role to the marine food webs (Vonk et al. 2008).

Globally, there are only about 60 seagrass species distributed in the world, consisted of 13 genera and 5 families (Short et al. 2001), of which 7 seagrass species of 5 genera have been recognized around Kapoposang coastal waters, namely Enhalus acoroides, Thalassia hemprichii, Cymodocea rotundata, Syringodium isoetifolium, Halodule uninervis, Halophila minor, and Halophila ovalis (MCRMP 2007). Unfortunately, information about their distribution and habitat structure have not been well documented.

Kapoposang Island has been appointed by the Ministry of Marine Affairs and Fisheries Republic of Indonesia through the Ministrial Decree 99 of 2009 as a part of waters tour parks in South Sulawesi (DKP 2009). Accordingly, marine resources, including seagrass ecosystems, in the surrounding waters of this 
island should be well protected and managed in order to provide biodiversity protection and sustainable use of the seagrass ecosystems. For this purpose, information of seagrass distribution and habitat structure is required, because continuity, density, complexity and heterogeneity of the seagrass beds will influence the fauna assemblage, including fish in the seagrass beds (Gulltsröm 2002; Hyndes et al 2003).

A model of ecological habitat structure has been created by Bell et al. (1991). The model consists of three major variables (1) complexity, (2) heterogeneity, and (3) scale. Complexity is the variation attributable to absolute abundance of individual structural components. Heterogeneity includes variation attributable to the relative abundance of different structural components. Scale emphasizes that the first two components must be commensurate with the dimensions of the organisms being studied. Such model may be applied in identifying various habitat structures, including seagrass habitat. This study was aimed to (1) observe the location of continues seagrass beds, (2) identify the habitat structure in each site of continues seagrass beds.

\section{Research Methods}

The study was carried out during July 2010 in coastal waters surrounding Kapoposang Island, located in the outer zone and at the most west part of Spermonde Archipelago (04 ${ }^{\circ} 41^{\prime}$ to $04^{\circ} 43^{\prime} \mathrm{S}$ and $118^{\circ} 56^{\prime}$ to $118^{\circ} 59^{\prime} \mathrm{E}$ ) (Figure 1). Very extensive (296.75 ha) multispecies seagrass vegetation (DKP 2009) occur in the surrounding waters of this island. The surrounding waters is characterized by transparent oligotrophic waters, especially phosphate and nitrate concentrations are extremely low compared to the surrounding waters of Barrang Lompo, and the effects of upwelling near the shelf rim (Figure 1) occur during dry season (Troelstra et al. 1996). Kapoposang is coral island, comparable to Barrang Lompo and Langkai islands, surrounded by large intertidal reef flat, which consist of coarse carbonate sand and coral rubble (93-100\% CaCO3; Erftemeijer \& Middelburg 1993).

Continues seagrass beds were observed visually along the coastal waters surrounding Kapoposang Island. To obtain representative observation of the study area, transect method was applied. Seagrass beds that occurred from the inshore to over $100 \mathrm{~m}$ off the coast to deeper sub-tidal areas where coral habitats begin to dominate were determined as continues seagrass beds, hence those were less than $100 \mathrm{~m}$ were not included in this observation. Geographic position of inshore end as the start of the transect line was recorded as the site of each observed continues seagrass beds.

The seagrass structure in each site of continues seagrass bed was identified based on complexity and heterogeneity level as suggested by an ecological habitat structure model of Bell et al. (1991) (Figure 2) and following Hamylton \& Spencer (2007). In this study, a term "component" in the suggested model of Bell et al. (1991) was analogous to seagrass species, as well as algae and coral that usually accompany in the seagrass beds. A term of "individual number of component" was analogous to cover percentage of each species. This was similar with the previous work done by Hamylton \& Spencer (2007), who also used seagrass cover as "individual number of component", however they measured the seagrass cover using a Compact Airbone Spectrographic Imager (CASI).

All of the seagrass species found within each quadrate was identified following (Kuo \& den Hartog 2006; McKenzie et al. 2003) and the present algae and coral (if any) was also recorded. This will then be used for determining the habitat heterogeneity of each seagrass beds. The percent contribution of each seagrass species, including algae and coral, to the total cover of seagrass within the quadrates was estimated based on the guidance of percent cover photo standards (McKenzie et al. 2003), and the value will then be used to determined habitat complexity level. The average value of seagrass cover of all quadrate replicates was then obtained as the estimate of total seagrass percent cover for each site.

In this study, seagrass cover percentage was estimated using a combination method of a transect line and quadrates following English et al. (1994) and Mckenzie et al. (2003). A transect $(100 \mathrm{~m})$ was located randomly to the seagrass beds along a shoreline of the island. Position of the transect was perpendicular to the shore and six replicate quadrates $(1 \times 1 \mathrm{~m})$ were placed side by side along the transect line. The distance of each quadrate was $20 \mathrm{~m}$ (Figure 3).

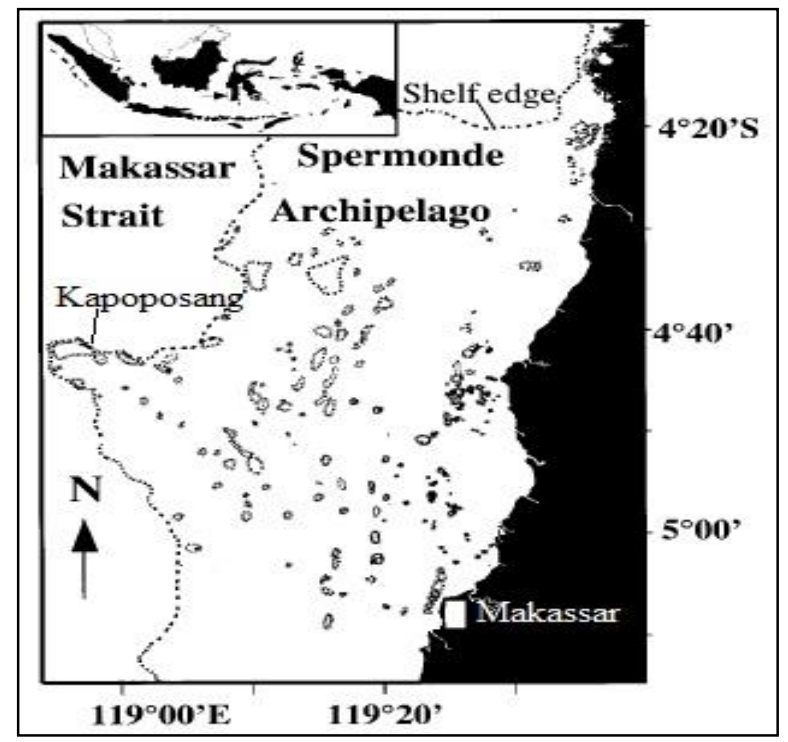

Figure 1 Location of Spermonde Archipelago South Sulawesi and the study area mentioned in the text (Modified from Stapel et al. 2001) 


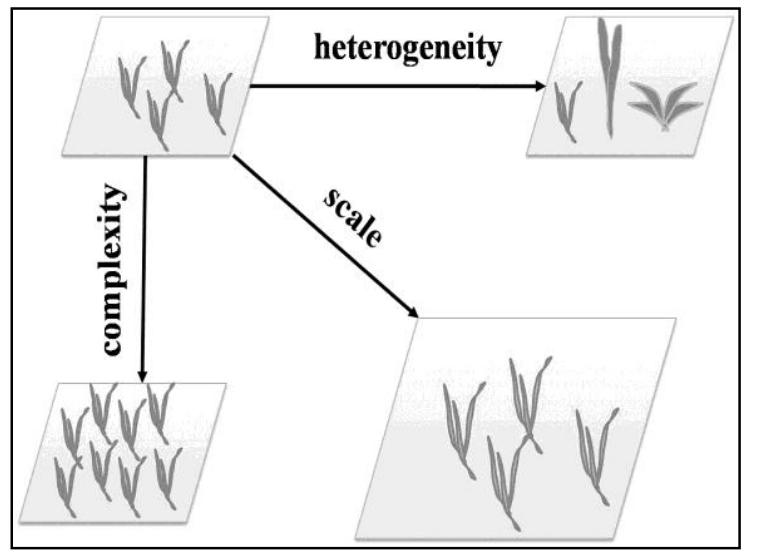

Figure 2 A graphical model of habitat structure (modified from Bell et al. 1991)

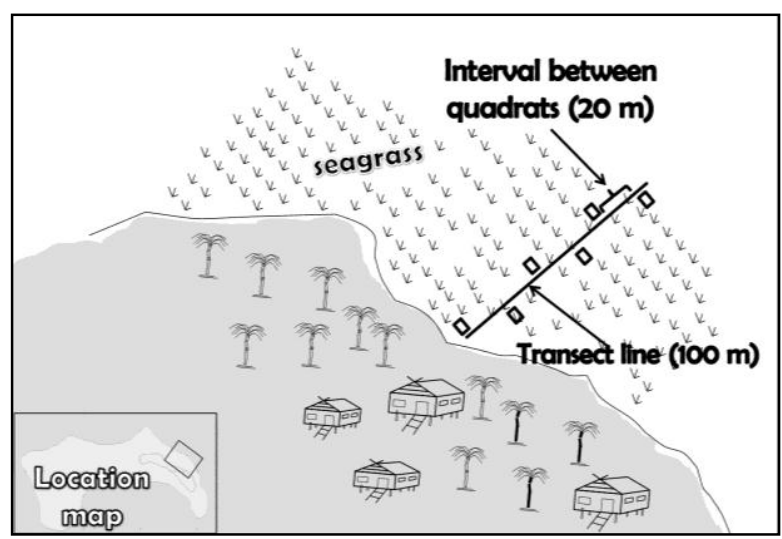

Figure 3 Position of transect line and quadrates for seagrass cover estimation in the continues beds of Kapoposang Island

\section{Results and Discussion \\ Continues seagrass beds}

The observation result showed that there were five sites of continues seagrass beds along the shoreline of Kapoposang Island (Figure 4). Site A was located at the geographic position of S04\%1'42.5"; E118 $56^{\prime} 59.5^{\prime \prime}$, site B was at the position of S04\%1'48.8"; E118 $56^{\circ} 57.7^{\prime \prime}$, site C was at S04'41'52.5"; E118 $57^{\prime} 00.3^{\prime \prime}$, site D was at S04 $41^{\prime} 56.7^{\prime \prime} ;$ E118 $57^{\prime 20.3 ",}$ and site E was at S04'41'57.8"; E118 57'45.7'". Other than those five sites were patchy seagrass beds, sandy bare area, and coral reefs. This result was supported by the the report of MCRMP (2007) who reported that in the surrounding waters of Kapoposang Island comprised various habitats including seagrass beds, sandy bare areas and coral reefs, although a detail geographic position for the seagrass beds was not described in the report and more focused on the condition of coral reef only.

\section{Seagrass beds structure}

During the observation, there were 7 taxa were found in those five continues seagrass beds, but only 5 of them could be identified to the species level and 2 taxa was identified to the genus level only (Halophyla $\mathrm{sp}$, Figure 5). There was a difficulty in the field to distinguish between Halophila minor and $H$. ovalis due to their small size and similarity in shape. As both of them contributed less to the seagrass community, their identification to the genus level was not significantly influence the determination of seagrass complexity and heterogeneity. All seagrass species found in this study result support the previous finding of MCRMP (2007) who described the seagrass species occurrence in waters of Kapoposang island, but there was no other explanation about their spatial distribution.

Seagrass species composition and their coverage were in variable in each of those five continues seagrass bed sites (Table 1), however the most frequent species found in all sites were Thalassia hemprichii and Enhalus acoroides. This indicating that both of them were the most common seagrass species in the waters of Kapoposang Island, and the result is consistent with the explanation of Tomascik et al. (1997) that both of them were the most common and abundant tropical seagrass species in Indonesian waters. Both of these species have similar strap-like leaves shapes, but different in length and wide. $T$. hemprichii has shorter leaves (10-40 cm long, 0.5$1 \mathrm{~cm}$ wide) compare with the much greater leaf lengths of E. acoroides (30-150cm long, approximately $1-2 \mathrm{~cm}$ wide). Among the five sites of continues seagass beds, there were only two sites (A and E) had the highest (>80\%) seagrass cover (Figure 6).

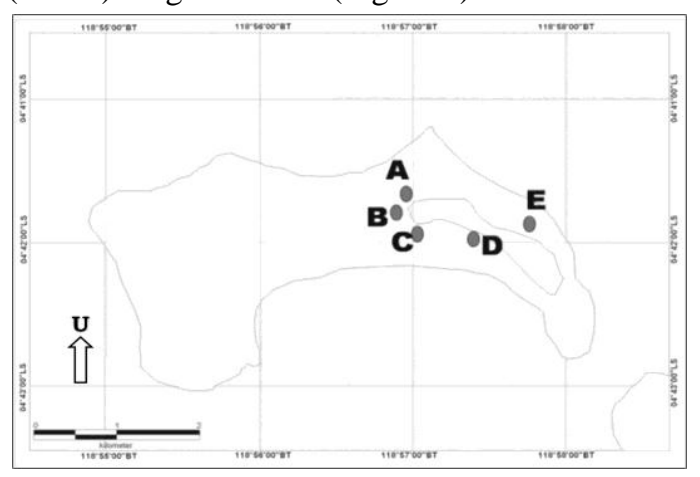

Figure 4 Five sites (A, B, C, D, E) of continues seagrass beds along the shoreline of Kapoposang Island

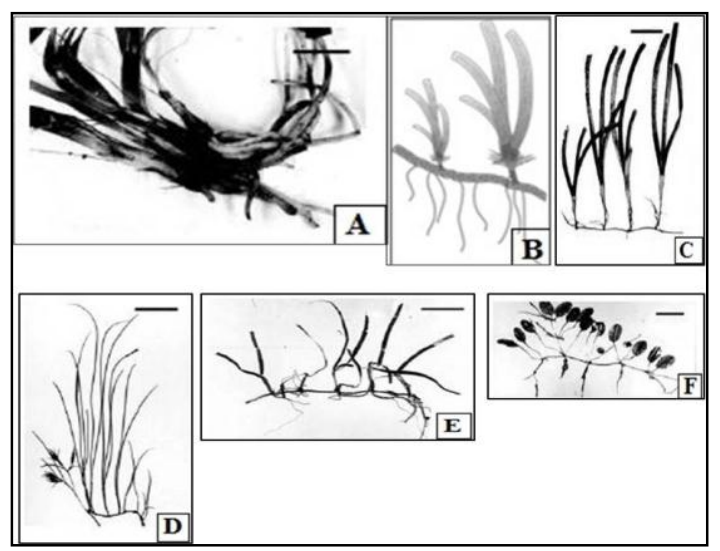

Figure 5 Seagrass species in the continues beds around coastal waters of Kapoposang Island. A = Enhalus acoroides, $\mathrm{B}=$ Thalassia hemprichii, $\mathrm{C}=$ Cymodocea rotundata, $\mathrm{D}=$ Syringodium isoetifolium, $\mathrm{E}=$ Halodule uninervis, $\mathrm{F}=$ Halophila sp. Bars indicated $3 \mathrm{~cm}$. All pictures adapted from Kuo \& den Hartog (2006), except for B was adapted from Collier (2008) 


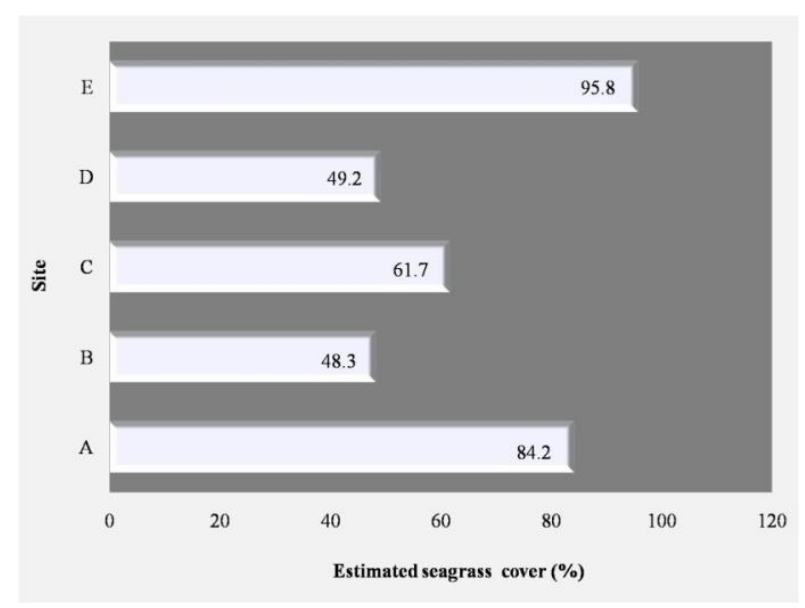

Figure 6 Estimated average seagrass percent cover of continues seagrass beds in the surrounding waters of Kapoposang Island

Both sites comprising a different seagrass species composition, and minor coral and algae cover. Site A was dominated by T. hemprichii (seagrass cover was 74.2 of $84.2 \%$ ) and site $E$ was dominated by $E$. acoroides (75 of 95.8\%). As both species have different size of leaves (in length and wide), indicate that structural architecture of seagrass beds in site A (dominated by $T$. hemprichii) will be different with the one dominated by $E$. acoroides in site E. It is because they will provide different canopy height, especially during high tide or when they submerged in the waters. The difference in complexity structural of the seagrass beds may harbor fish and other fauna in different community assemblages. As showed by Hyndes et al. (2003) that fish assemblages differed evidently among three distinct seagrass habitats that structurally different from each other, due to differences in such as leaf canopy, leaf area index, and landscape configuration.

Although they may different in harboring fish community structure, both seagrass beds dominated by
T. hemprichii (site A) and E. acoroides (site E) may play a better role (compare with other three sites that have less seagrass cover) in controlling coastal biogeochemistry (Marba et al. 2006) due to the complex architecture of the leaf canopy in combination with the dense network of roots and rhizomes (Hemminga \& Duarte 2000; Gullstrom \& Dahlberg 2004). The role of seagrass beds are including stabilize bottom sediments and serve as effective hydrodynamic barriers to reduce wave energy, current velocity, turbidity and decrease erosion.

Related to complexity and heterogeneity level, Hamylton \& Spencer (2007) found that seagrass habitat located in moderate wave impact supported high complexity and heterogeneity, while the more sheltered area characterized by low complexity and intermediate to high heterogeneity, and the most exposed area support low complexity and low heterogeneity. Although detailed studies of wave exposure effects on the seagrass have not been done yet in Kapoposang Island, Hamylton \& Spencer (2007) found that high natural wave disturbance result in only species tolerant to the stress can persist.

In Kapoposang Island, heterogeneity level (based on number of species) of site A was less than site E (Table 1). This could be due to site A was located in more wave exposed area compare with site E. However, in general, the location of Kapoposang Island in the most outer part of Spermonde Arhipelago indicating that this island faces directly to the open area of Makassar Strait and thus, this island experiences more wave exposure compare with other small islands that located in the inner part of the archipelago (Figure 1). Consequently both sites (A and E) tended to be dominated by one species only (Table 1), indicating the low complexity level of both sites. More laboratory works and field testing are required to compare and determine the effect of wave exposures on various seagrass species in several different location.

Table 1 Estimated seagrass and coral percent cover of continues seagrass beds in the surrounding waters of Kapoposang Island

\begin{tabular}{|c|c|c|c|c|c|c|c|c|c|}
\hline \multirow{2}{*}{$\begin{array}{c}\text { Geographic } \\
\text { position }\end{array}$} & \multirow{2}{*}{ Site } & \multicolumn{6}{|c|}{$\%$ cover of each seagrass species } & \multirow{2}{*}{$\begin{array}{c}\% \text { algae } \\
\text { cover }\end{array}$} & \multirow{2}{*}{$\begin{array}{c}\% \text { coral } \\
\text { cover }\end{array}$} \\
\hline & & $E A$ & $T H$ & $C R$ & $S I$ & $H U$ & $H L$ & & \\
\hline 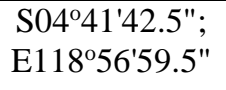 & A & 0.0 & 74.2 & 1.8 & 2.3 & 0.0 & 0.0 & 0.0 & 5.8 \\
\hline $\begin{array}{l}\text { S0441'48.8"; } \\
\text { E118 }\end{array}$ & B & 5.8 & 35.0 & 0.0 & 7.5 & 0.0 & 0.0 & 0.0 & 0.0 \\
\hline $\begin{array}{l}\text { S04 } 41^{\prime} 52.5^{\prime \prime} \\
\text { E118 } \\
7^{\circ} 00.3^{\prime \prime}\end{array}$ & $\mathrm{C}$ & 8.3 & 45.3 & 0.0 & 0.0 & 0.0 & 0.5 & 0.0 & 7.5 \\
\hline $\begin{array}{l}\text { S04 } 41^{\circ} 56.7^{\prime \prime} \\
\text { E118 } \\
7^{\circ} 20.3^{\prime \prime}\end{array}$ & $\mathrm{D}$ & 6.5 & 39.8 & 0.8 & 1.0 & 0.0 & 0.5 & 0.0 & 0.5 \\
\hline $\begin{array}{l}\text { S04 } 41^{\circ} 57.8^{\prime \prime} \\
\text { E118 }\end{array}$ & $\mathrm{E}$ & 75 & 15 & 2.5 & 0.8 & 0.8 & 0.0 & 0.8 & 0.8 \\
\hline
\end{tabular}

EA: Enhalus acoroides, TH: Thalassia hemprichii, CR: Cymodocea rotundata, SI: Syringodium isoetifolium, HU: Halodule uninervis, HL: Halophila sp. 


\section{Conclusion}

There were five sites of continues seagrass beds along the coastal waters of Kapoposang Island. There were two sites with highest seagrass cover, namely site $A$ in north-west part and site $E$ in north part of Kapoposang Island. Both sites have different habitat structures. Site A characterized by low heterogeneity and complexity and was dominated by Thalassia hemprichii, meanwhile site $\mathrm{E}$ had high heterogeneity and low complexity and was dominated by $E$. acoroides.

\section{Suggestion}

More studies on the assessment of wave exposure effects on seagrasses are required to provide a contribution for restoration effort, especially in the threatened seagrass habitat.

\section{References}

Bell SS, McCoy ED, Mushinsky HR. 1991. Habitat Structure The physical arrangement of objects in space. London: Chapman \& Hall. p 3-27.

Collier C. 2008. IAN image library: ian-symbolthalassia-hemprichii-2.svg.kbentsen/Seagrass/ SAV. Tersedia pada: http//ian.umces. edu/ imagelibrary.

[DKP] Dinas Kelautan dan Perikanan. 2009. Penyusunan rencana zonasi pilau-pulau kecil di Kapupaten Pangkajene dan Kepulauan. Lokasi terpilih: Taman Wisata Perairan (TWP) Kapoposang dan laut sekitarnya. Draft Laporan Akhir. Direktorat Tata Ruang Laut Pesisir dan Pulau-pulau kecil. Direktorat Jenderal Kelautan Pesisir dan Pulau-pulau Kecil Departemen Kelautan dan Perikanan.

English S, Wilkinson C, Baker V. 1994. Survey manual for tropical marine resources. Townsville: Australian Institute of Marine Science.

Erftemeijer PLA, Middelburg JJ. 1993. Sedimentnutrient interactions in tropical seagrass beds: a comparison between a terrigenous and a carbonate sedimentary environment in South Sulawesi (Indonesia). Marine Ecology Progress Series. 102:187-198.

Gullström M. 2002. Seagrass ecosystems in the Western Indian Ocean. Ambio. 31:588-596.

Gullström M, Dahlberg M. 2004. Fish community structure of seagrass meadows around Inhaca Island, southern Mozambique [Study Report]. Stockholm: Department of System Ecology, Stockholm University, Sweden.
Hamylton S, Spencer T. 2007. Classification of seagrass habitat structure as a response to wave exposure at Etoile Cay, Seychelles. EARSel eProceeding. 6(2):94-100.

Hemminga MA, Duarte CM. 2000. Seagrass Ecology. New York: Cambridge University Press. 298 p.

Hyndes GA, Kendrick AJ, MacArthur LD, Stewart E. 2003. Differences in the species- and sizecomposition of fish assemblages in three distinct seagrass habitats with differing plant and meadow structure. Mar Biol. 142:11951206.

Koch EW, Sanford LP, C. Shih-Nan, Shafer DJ, Smith JM. 2006. Waves in Seagrass Systems: Review and Technical Recommendations. System-Wide Water Resources Program Submerged Aquatic Vegetation Restoration Research Program. Engineer Research and Development Center. ERDC. U.S. Army Corps of Engineers, Washington, D.C. p 82.

Kuo J, den Hartog C. 2006. Taxonomy and Biogeography of Seagrasses. In: Larkum AWD, Orth RJ, Duarte CM, editors. Seagrasses: Biology, Ecology and Conservation. Netherland: Springer. p 1-23.

.2006. Seagrass morpholopgy, anatomy and ultrastructure. In: Larkum AWD, Orth RJ, Duarte CM, editors. Seagrasses: Biology, Ecology and Conservation. Netherland: Springer. p 51-87.

Marbà N, Holmer M, Gacia E, Barrón C. 2006. Seagrass Beds and Coastal Biogeochemistry. In: Larkum et al., editors. Seagrasses: Biology, Ecology and Conservation. Netherland: Springer. p 135-157.

[MCRMP] Marine and Coastal Resources Management Project. 2007. Detailed Survey and Mapping of Selected Areas [Final Report]. A Collaborative work among MCRMP, Bappeda Sulsel, and CV. Nature Bestari [in Indonesian Language].

McKenzie LJ, Campbell SJ, Roder CA. 2003. Seagrass-Watch: Manual for Mapping \& Monitoring Seagrass Resources by Community (Citizen) Volunteers. Cairns: QFS,NFC. p 100.

Rasheed MA, Dew KR, Kerville SP, McKenzie LJ, Coles RG. 2006. Seagrass Distribution, Community Structure and Productivity for Orman Reefs, Torres Strait - March and November 2004. DPI Information Series QI06088 (DPI, Cairns). p 38. 
JPSL Vol.(2)1: 11-16, Juli 2012

Short FT, Coles RG, Pergen-Martini C. 2001. Global seagrass distribution. In: Short FT, Coles RG, editors. Global Seagrass Research Methods. Netherland: Elsevier Science BV. p 1-4.

Stapel J, Hemminga MA, Bogert CG, Maas YEM. 2001. Nitrogen $(15 \mathrm{~N})$ retention in small Thalassia hemprichii seagrass plots in an offshore meadow in South Sulawesi, Indonesia. Limnol. Oceanogr. 46(1): 24-37
Tomascik T, Mah AJ, Nontji A, Moosa MK. 1997. The Ecology of Indonesian Seas. Part II. The Ecology of Indonesia Series, Volume VIII. Periplus Editions, Singapore. p 746.

Troelstra SR, Jonkers HM, de Rijk S. 1996. Larger foraminifera from the Spermonde Archipelago (Sulawesi, Indonesia). Scripta Geol. 113:93120.

Vonk JA, Christianen MJA, Stapel J. 2008. Redefining the trophic importance of seagrasses for fauna in tropical Indo-Pacific meadows. Estuar. Coast Shelf S. 79:653-660. 